\title{
COMPETING WITH OURSELVES: SUPPLY-SIDE COMPETITION FOR CORPORATE CHARTERS IN CANADA
}

\author{
GLENFORD JAMESON*
}

This article considers the Canadian interjurisdictional corporate law framework and assesses whether, from a supply side, there is a competitive market for corporate charters in Canada. The article considers two opposing views on whether Canadian corporate law jurisdictions compete with each other and discusses political, legal, and institutional barriers to competitive corporate law production in Canada. Corporate law reform in Quebec, specifically the development of the Quebec Business Corporations Act, is examined as an example of how barriers to corporate competition can be overcome.
Cet article examine le cadre intergouvernemental $d u$ droit des associés canadien et détermine si, du point de vue de l'offre, il existe un marché concurrentiel pour les chartes d'associés au Canada. L'article examine deux points de vue opposés, c'est-àdire si les compétences juridiques en matière de droit des associés au Canada se rivalisent entre elles, et traite des obstacles politiques, juridiques et institutionnels au droit des associés concurrentiel au pays. La réforme du droit associatif québécois, tout particulièrement l'adoption de la Loi sur les sociétés par actions est examinée à titre d'exemple de la manière de surmonter les obstacles à cette concurrence.

\section{TABLE OF CONTENTS}

I. INTRODUCTION: COMPETITION IN CANADA . . . . . . . . . . . . . . . . . . 844

II. ThE EFFECT OF COMPETITION: A THEORETICAL BASIS . . . . . . . . . . 845

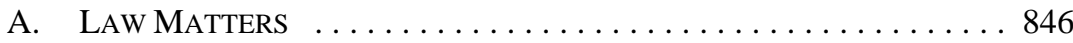

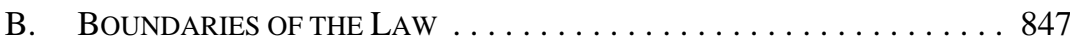

C. THE RACES: GOVERNMENT AND MARKET

DISCIPLINE SCHOOLS . . . . . . . . . . . . . . . . . . . 848

D. Public Choice / Interest Group Theory . . . . . . . . . . . . . 849

E. Regulatory Hostage Theory . . . . . . . . . . . . . . . 850

F. THE RELEVANCE OF COMPETITION THEORIES

TO THE CANADIAN CONTEXT . . . . . . . . . . . . . . . 850

III. CANADIAN RESEARCH ON CHARTER COMPETITION . . . . . . . . . . . . . 851

A. Daniels: Should Provinces Compete? . . . . . . . . . . . . 851

B. CumMing AND MACINTOSH:

THE ROLE OF INTERJURISDICTIONAL COMPETITION . . . . . . . . . . 851

C. A CRITICAL Response to CUMMING AND MACINTOSH . . . . . . . 857

IV. QueBeC AND THE QUEBEC BUSINESS CORPORATIONS ACT . . . . . . . . . 858
A. THE DEVELOPMENT OF THE
QUEBEC BUSINESS CORPORATIONS ACT . . . . . . . . . . . . 859

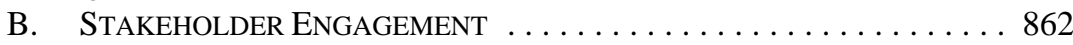
C. THE QUEBEC BUSINESS CORPORATIONS ACT,

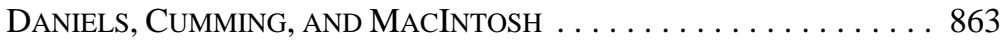

BA (Hons) (Mount Allison University), JD (Dalhousie). Mr Jameson is a lawyer in Toronto with a broad corporate-commercial practice. He is an executive member of the Charities and Not-for-Profits section of the Ontario Bar Association and advises co-ops, start-ups, and other organizations considering creative models of doing business. 
D. QUEBEC EMBRACES SuPPLY-Side COMPETITION . . . . . . . . . . . 864

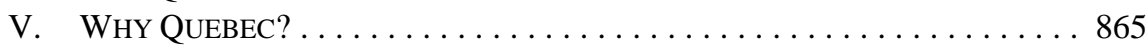

A. Cultural Interests $\ldots \ldots \ldots \ldots \ldots \ldots \ldots \ldots \ldots \ldots$

B. The Cultural Aspect of Public Interest Theory . . . . . . . 867

VI. Conclusion $\ldots \ldots \ldots \ldots \ldots \ldots \ldots \ldots \ldots \ldots \ldots \ldots \ldots \ldots$

\section{INTRODUCTION: COMPETITION IN CANADA}

This article considers the Canadian interjurisdictional corporate law framework and assesses whether, from a supply side, there is a competitive market for corporate charters in Canada. In the Canadian context, previous research on the domestic corporate charter market has been conducted only twice in the past 20 years.

In 2000, corporate and securities law professors Douglas Cumming and Jeffrey MacIntosh, of the Universities of Alberta and Toronto respectively, co-wrote "The Role of Interjurisdictional Competition in Shaping Canadian Corporate Law." ${ }^{\text {"1 }}$ Their work is the only thorough academic treatment of the competition question in Canada since Ronald J. Daniels researched the effects of the Canada Business Corporations Act ${ }^{2}$ in his 1991 essay, "Should Provinces Compete? The Case for a Competitive Corporate Law Market.”3

These two papers present distinctly different views on whether Canadian corporate law jurisdictions compete with each other. Daniels argued that the creation of the $C B C A$ vaulted Canada into an era of corporate law competition. Conversely, Cumming and MacIntosh considered Daniels' characterization of the evidence and questioned whether "the high degree of uniformity of provincial corporation laws achieved since 1975 [is] more likely to be a product of a charter market or a drive to uniformity? We would argue that, prima facie, it is more likely to be the latter." ${ }^{4}$ Cumming and MacIntosh suggested that jurisdictions instinctually converge toward the same corporate laws, rather than achieve uniformity through competition. ${ }^{5}$ Their study indicates that there are several significant political, legal, and institutional barriers to competitive corporate law production, which have prevented the establishment of a charter market in Canada. Among these hurdles are the lack of a competitive consciousness amongst bureaucrats and the electorate alike, a civil service that prefers leisure to work, limited governmental human and capital resources to devote to corporate law development, the encroaching nature of securities regulation, the nature of the Canadian judiciary and jurisprudence, a comparatively unskilled corporate bar and bench, and the lack of a close relationship between the corporate bars and corporate legislators. Cumming and MacIntosh highlight the case of Quebec as a jurisdiction that is naturally averse to competition because of political issues beyond the institutional problems above.

Douglas J Cumming \& Jeffrey G MacIntosh, "The Role of Interjurisdictional Competition in Shaping Canadian Corporate Law” (2000) 20:2 Int'l Rev L \& Econ 141.

RSC 1985, c C-44 [CBCA].

Ronald J Daniels, "Should Provinces Compete? The Case for a Competitive Corporate Law Market" (1991) 36:1 McGill LJ 130.

Supra note 1 at 160 .

Ibid. 
In the years since the research by Daniels, Cumming, and MacIntosh, there have been significant changes to several Canadian corporate acts; British Columbia (2000), ${ }^{6}$ the federal CBCA (2001), Alberta (2003), ${ }^{7}$ and Ontario (2006) ${ }^{8}$ have reformulated a significant number of their respective corporate law provisions. The most recent and thorough reform has been Quebec's 2011 transition from the Quebec Companies Act ${ }^{9}$ to the Quebec Business Corporations Act. ${ }^{10}$ At the same time, the Canadian economy has increasingly attracted international investment, resulting in new demand from the international business community for different legal products and features, and generally for streamlined incorporation. These changes have presented new supply-side evidence to evaluate charter competition in the face of Cumming and MacIntosh's claims of Canada's uniformity-driven charter market.

By critically placing Cumming and MacIntosh's arguments in the context of Canadian corporate law developments since 2000, it becomes clear that the "uniformity hypothesis" does not account for several developments. ${ }^{11}$ The drive of jurisdictions to offer new products and features as well as the significant changes to several provincial acts indicate that competition is in the minds of bureaucrats, legislators, and the corporate bars. Most notable however, is the development of the $Q B C A$. Legislators expressly stated that the goal of the $Q B C A$ reform was to create a superior body of corporate legislation to induce companies to forum shop, that is, to consider Quebec as an alternative jurisdiction to incorporate in. The development of the $Q B C A$ offers clear evidence of intended competition in corporate legislation in Canada.

Quebec, by reforming their corporate laws with the intent to compete, bridges many of the perceived barriers to supply-side competition identified by Cumming and MacIntosh. By considering public interest or interest group theory and examining the context in which the $Q B C A$ evolved, this article identifies non-economic, cultural-linguistic motives for explaining Quebec's legislative path to the QBCA. While institutional barriers still exist that will likely work to prevent Canada from engaging in competition on a level seen in the United States, it is clear that most other barriers can be easily overcome.

\section{THE EFFECT OF COMPETITION: A THEORETICAL BASIS}

Daniels, Cumming, and MacIntosh's research has primarily focused on whether charter competition exists in Canada. Their arguments identified possible barriers and evidence to support their positions. Once competition is found to exist, the next task is to create explanations to predict how corporate legislators may compete, and to predict who stands to benefit from competition.

In the US, the notion of whether the freedom to choose corporate law benefits shareholders is routinely held as "[o]ne of the most important questions in U.S. corporate

Business Corporations Act, SBC 2002, с 57 [BCBCA].

Business Corporations Act, RSA 2000, c B-9.

Business Corporations Act, RSO 1990, с B.16.

RSQ, c C-38 [QCA].

RSQ, c S-31.1 [QBCA].

For a discussion of the uniformity hypothesis see Cumming \& MacIntosh, supra note 1 at 158-60. 
law." ${ }^{12}$ In Canada, the US, and the European Union, firms have flexibility in choosing which jurisdiction to incorporate in, irrespective of whether a firm intends to do business there. More attractive corporate statutes will encourage more corporate charters, resulting in ancillary corporate services and charter revenues for the jurisdiction. This theoretically leads to competition for jurisdictions to provide the most competitive laws possible. If competition for corporate charters exists amongst states, provinces, or EU members, then a system of supply and demand for corporate legislation should exist. The economic analogy for legislation suggests that competition results in more efficient corporate laws. With increased efficiency, a convergence of laws should occur. As much as competing firms settle on optimal pricing while innovating, competition is thought to result in efficient and relatively uniform corporate laws.

For over 30 years scholars have advanced significantly differing theories in attempts to explain the American corporate charter landscape and its dominant player, the state of Delaware. Since the creation of the EU in the 1990s, significant attention has been placed on the Societas Europaea by academics in hopes of better understanding what factors impact the development of a competitive charter market. Jurists have given the subject of charter competition in the EU and the US significant attention.

There are six primary hypotheses that attempt to explain how the American charter landscape arose by assessing the roles of various stakeholders and their effect on corporate legislation: law matters, boundaries of the law, government discipline school, market discipline school, public choice / interest group theory, and regulatory hostage theory.

\section{A. LAW MATTERS}

The "law matters" hypothesis states that a superior quality of law in one jurisdiction will lead to significant benefits over a jurisdiction with inferior laws. The theory has most often been placed internationally, where approaches to similar problems have received different legal treatment. For example, law matters scholar Rafael La Porta has divided civil and common law jurisdictions to illustrate differences in liquidity and ownership concentration. ${ }^{13}$ The idea is that the law and subsequent enforcement of laws is at the cornerstone of the jurisdictional competition question. If law does not matter, then jurisdictions cannot compete by offering better or worse legislation.

To this end, John C. Coffee, in his seminal article "Do Norms Matter?," has suggested that it may be possible that the law simply does not matter when it comes to jurisdictional competition and that social norms play a pervasive yet unappreciated role in the protection of minority shareholders across corporate law jurisdictions. ${ }^{14}$ Coffee found that "societies with high crime and/or low social cohesion are also characterized by high private benefits

12 Guhan Subramanian, “The Influence of Antitakeover Statutes on Incorporation Choice: Evidence on the 'Race’ Debate and Antitakeover Overreaching” (2002) 150:6 U Pa L Rev 1795 at 1797.

13 Rafael La Porta et al, "Investor Protection and Corporate Governance” (2000) 58:1-2 Journal of Financial Economics 3. 
of control." ${ }^{15}$ Coffee identifies, as an example of the role that social norms can play, the situation in the US and the United Kingdom where the board of directors is generally independent of management yet there is no legal rule preventing managers from sitting on the board. ${ }^{16}$

Coffee argues that investors are aware of the intertwining of legal rules and social norms, and price this into investments as a form of shareholder value. In "Do Norms Matter?," Coffee chose the example of the private benefits of control because of the significant variations in different market jurisdictions to tolerate management's enjoyment of the fruits of corporate control, and the law matters scholarship that pointed to civil and common law backgrounds as the reason for the variance. ${ }^{17}$ Coffee identified that, while there is a correlation between civil and common law jurisdictions and the abuse of control, low victimization and crime rates also run in step with findings of restricted private benefits of control. ${ }^{18}$ The Coffee Norms Matter theory brings with it an interdisciplinary approach to the idea of regulatory competition between jurisdictions: you can change the law overnight, but you cannot change the social norms so easily. The relationship between firm value and a jurisdiction is primarily based on confidence and trust. Coffee writes: "[If] corporate behavior is as much or more driven by norms as legal rules, the importance of free competition in a market for legal rules would seem diminished or at least more open to question." ${ }^{19}$ According to Coffee, the value of a firm is tied to the culture and social norms of a jurisdiction rather than its laws.

\section{B. BOUNDARIES OF THE LAW}

The "boundaries of the law" theory advanced by Stanford Law School professor Michael Klausner, suggests that it is important to recognize that legislative regimes are limited in what they can and cannot achieve. In a similar thought to Coffee's Norms Matter thesis, Boundaries scholars suggest that legislating tools to enforce behaviour may be for nought, and that some things exist outside the influence of the law. Klausner identifies three sets of laws that are designed - but have failed — to force directors to govern in the interest of shareholders: (1) fiduciary duties that are actionable; (2) shareholder voting rules; and (3) securities laws that induce financial and operations disclosure. ${ }^{20}$ The boundaries argument holds that a director will not become fair and diligent because of heavy legislation, structure, and process. ${ }^{21}$ Klausner argues that economic solutions (that board members all own a significant percentage of the company) and stronger professional norms - not SarbanesOxley style legislation - are the best path to good governance. ${ }^{22}$ This suggests that Delaware enjoys the unique corporate law situation it does because of the social norms of the people of Delaware, rather than any legislative framework that governs corporations there.

Ibid at 2153.

Ibid at 2155-56.

Ibid at 2165 .

Ibid at 2166 .

Ibid at 2177.

Michael Klausner, “The Limits of Corporate Law in Promoting Good Corporate Governance” in Jay W Lorsch, Leslie Berlowitz, \& Andy Zelleke, eds, Restoring Trust in American Business (Cambridge, MA: MIT Press, 2005) 91-92.

$21 \quad$ Ibid at $95-96$.

22 Ibid. 


\section{THE RACES: GovernMENT AND MARKET DisCiPLinE SCHOOLS}

The most prominent theories on this idea of competition are "race-for-the-top" and "racefor-the-bottom" theories. Classically, academics have pooled at either the top or bottom end of the race. However, in recent years there has been a de-polarization of the discourse, as more substantive and empirical research has yielded results that indicate that competition may not be as heated as initially believed.

The "bottom" - or "government discipline" school — consists of corporate laws that allow managers to operate with the best interests of the corporation in mind rather than shareholder considerations of value maximization. William L. Cary suggested that management was in the driver's seat when choosing where to incorporate or reincorporate. ${ }^{23}$ It follows that, because management seeks protection from shareholders, jurisdictions aim to increase the number of corporations by offering greater protection to management to run the corporation without interference. One problem with this idea is that it leads to problems of high agency costs; the freedom of management to run without checks results in inefficiencies ranging from self-dealing and excessive compensation to expropriating opportunities that have arisen within the business. ${ }^{24}$

Conversely, the "top" of the "race-for-the-top" — also called the "market discipline" school - is a set of corporate laws that are best suited for shareholders because it primarily encourages the creation of shareholder value. The basis for this argument was stated by Ralph K. Winter, who submitted that efficient corporate control maximizes shareholder value and repels takeover bids. ${ }^{25}$ Winter concluded that: “(1) Contrary to the conventional wisdom, competitive legal systems should tend toward optimality so far as the shareholder's relationship to the corporation is concerned. (2) State corporation codes in fact seem quite consistent ... with what economic theory suggests are optimal legal arrangements." 26

As both defences to takeovers and high shareholder value are beneficial to all stakeholders, corporations will seek out jurisdictions that offer laws that are optimized for shareholder interests, the "top" laws. ${ }^{27}$ Investors are aware which states have sub-optimal laws and price the anticipated inefficiencies described above into shares of firms from those states. As the body of research that discusses regulatory competition in corporate law has grown, so too have the viewpoints and theories that explain why states act as they do. With respect to the top-bottom arguments, most scholars have softened their stances on both ends of the academic spectrum and now rest somewhere in between Cary and Winter. Roberta Romano, for example, suggests that it is misguided to think of Delaware corporate law in broad strokes as generally favouring shareholders or managers. ${ }^{28}$ Her research suggests that a healthy mix of shareholder- and management-preferred laws exist in Delaware, rather than one or the other. Romano also identified several laws that do not offer advantages to either

William L Cary, “Federalism and Corporate Law: Reflections Upon Delaware” (1974) 83:4 Yale LJ 663. Eric Kades, "Freezing the Company Charter” (2000) 79:1 NC L Rev 111 at 146.

Ralph K Winter, Jr, “State Law, Shareholder Protection, and the Theory of the Corporation” (1977) 6:2 J Legal Stud 251.

Ibid at 254.

Ibid.

Roberta Romano, “The State Competition Debate in Corporate Law” (1987) 8:4 Cardozo L Rev 709. 
group, but remain stable and clear elements of the corporate code, which enable Delaware corporate law to operate in a predictable manner. ${ }^{29}$ Most importantly, in the case of Delaware, Romano identifies the dependence of the state on revenue directly and indirectly generated from incorporations. ${ }^{30}$

\section{Public ChOICE / INTEREST Group THEORY}

A perspective on the cause and effect of state versus federal corporate law competition is public choice theory. Public choice theory is interchangeable with the term interest group theory. This economic theory was developed to address regulation in a general manner and has since been applied to corporate law competition by Jonathan Macey and Mary E. Kostel. Kostel describes the theory as having three factions: "[T]hose who demand legislation, those who supply legislation (by bearing its costs), and legislators, who broker the exchange.”31 The theory uses the concept of "rents" to describe the impetus for the legislators to favour either faction. This comes in the form of honoraria, campaign contributions, and various other financial and non-financial forms of support. ${ }^{32}$ Kostel continues with this theory: "The more effectively a voting group can 'pay' the legislator, the more likely it is that the legislator will create and support legislation that is favorable to that group." ${ }^{33}$ The more effectively a group can organize to pay, the more the group can expect legislation to be favourable. Smaller groups within supply and demand factions will trade votes to increase the lobbying capital it has to pay, thereby maximizing the power of various sub-factions. ${ }^{34}$

Kostel argues that this theory explains why legislation can have a stated purpose that is inconsistent with the actual function of the law. ${ }^{35}$ She identifies this gap in corporate law in the US, suggesting that the "theory helps explain why legislation that is avowedly aimed at protecting shareholders is in fact motivated by a drive to protect incumbent management." ${ }^{\text {"36 }}$ Implying that shareholders are not closely-knit groups that are as identifiable as the managers of a firm, Kostel sees the greatest inconsistencies arriving out of jurisdictions that do not have effective lobbying groups. In the case of Delaware, corporate law favours the bankers and lawyers who provide services to Delaware companies. In a wonderfully pithy example of public choice theory at work, Romano wrote:

[S]ince most restrictions imposed by [valid anti-takeover] statutes can be adopted voluntarily by charter amendment without an authorizing statute, management's lobbying for legislation clearly implies that it believes it easier to convince a state legislature than shareholders of an antitakeover provision's desirability. ${ }^{37}$

Ibid at 721-22.

Ibid at 721-24.

Mary E Kostel, “A Public Choice Perspective on the Debate over Federal Versus State Corporate Law” (1993) 79:8 Va L Rev 2129 at 2138.

Jonathan R Macey, "Federal Deference to Local Regulators and the Economic Theory of Regulation: Toward a Public-Choice Explanation of Federalism” (1990) 76:2 Va L Rev 265 at 269.

Supra note 31 at 2138 .

Ibid.

Ibid at 2139.

Ibid.

Roberta Romano, The Genius of American Corporate Law (Washington, DC: AEI Press, 1993) 84. 
Romano sees certain constituencies as having direct and significant impacts on the corporate legislative regimes of states. By using public choice theory to explain how legislation is determined, director-favourable legislation arises where competition is most apparent.

\section{E. Regulatory Hostage THEORY}

As an extension of public choice, Erik Kades and Roberta Romano see the make-up of laws as favouring specific interest groups - the corporate bar, in particular - in what Romano sees as an example of regulatory hostage theory.

Kades and Romano suggest that both shareholders and management are held hostage by external interest groups. In Kades' paper evaluating the idea of the charter freeze, he suggests that a jurisdiction with strong interest groups outside of management and shareholders - the lawyers, bankers, forensic accountants, and so on — ought to consider freezing their charter as corporate statutes force companies to use lawyers more often through increased formalities and litigation. ${ }^{38}$

\section{F. THE RELEVANCE OF COMPETITION THEORIES TO THE CANADIAN CONTEXT}

Daniels, Cumming, and MacIntosh have looked only so far as to see if there is evidence of market forces that would suggest charter competition in Canada. Cumming and MacIntosh suggested that Canadian jurisdictions were content in mirroring the federal government, seeking to blend their legislation into a uniform set of laws across Canada. Daniels found evidence of competition in the years after the introduction of the $C B C A$. Daniels, Cumming, and MacIntosh's research comprises the canon of research on charter competition in the Canadian context, and their work has demonstrated evidence of much weaker charter competition than what is thought to exist in the US. Because their analysis is preoccupied with whether competition exists, they do not focus on explaining what drives jurisdictions to compete.

The competition question is important because, once established, the above theories help explain why legislators enact provisions that favour directors or shareholders and what factors drive a corporation to forum shop. The theories, above all, provide different accounts of what factors are primary in creating a competitive corporate legislative body, and whose interests are being defended. The theories presented above enable hypotheses about which constituencies are most likely to influence corporate laws, and which amendments are likely to encourage interjurisdictional forum shopping

Public choice theory offers the most compelling account of competitive corporate law development in Canada, and particularly Quebec. This is primarily examined through evidence presented later in this article regarding the development of the $Q B C A$. The underlying focus on individual constituencies costs of paying rents enables the theory to be applied flexibly with regard to the corporate make-up in any given jurisdiction. 
Explanations that suggest competition for charters races toward shareholder- or directorcentric laws need to be placed in context. As Romano argues, it is unlikely that broad strokes can be taken from either the government or market discipline schools; the results will vary depending on the characteristics of the sample of companies used to evidence a race to the bottom or top.

The law matters hypothesis is a valuable way of looking at crime statistics, and the extortion of the benefits of private control, as in Coffee's fascinating "Do Norms Matter?" essay. However, evidence of law matters is best shown when applied to questions of enforcement and efficacy across foreign borders, rather than across state or provincial lines where norms are likely to be more consistent. As a way of considering the competition question, law matters is not useful within Canada. Likewise, boundaries of the law presents a compelling view of the free will of a corporation, and perhaps it helps explain why so little corporate law reform was undertaken in early and mid-20th century Canada, but it fails to account for relationships between such similar jurisdictions.

\section{CANADIAN RESEARCH ON CHARTER COMPETITION}

\section{A. Daniels: Should Provinces Compete?}

In 1991, Daniels, former Dean of the University of Toronto Law School, published a study that sought to assess whether competitive forces existed in Canada as in the US. ${ }^{39}$ Daniels' study primarily focused on the modernization of Canadian corporate laws after the introduction of the $C B C A$ in 1975. Plotting the provinces' corporate statute amendments along a graph to indicate how adoptive the respective legislative regimes were, Daniels demonstrated that after the introduction of the $C B C A$, virtually every Canadian jurisdiction implemented significant changes to their own corporate laws within ten years of the federal Act, often mirroring the provisions contained in the $C B C A$. With each subsequent legislative amendment, the amending province adopted more $C B C A$ reforms. ${ }^{40}$

Daniels suggested that the markedly responsive legislating tactics that provinces undertook after the $C B C A$ was evidence that market forces were in effect in Canada, interpreting the amendments in corporate legislation as attempts to regain charter market shares that were lost to the comparatively modern $C B C A$.

\section{B. CUMMING AND MACINTOSH:}

\section{THE ROLE OF INTERJURISDICTIONAL COMPETITION}

Cumming and MacIntosh re-evaluated Daniels’ work in 2000 and presented an alternative hypothesis to describe the Canadian corporate law market: one of uniformity. ${ }^{41}$ Cumming and MacIntosh described their differences with Daniels: “[W]hat divides us is, to a considerable extent, a question of emphasis on matters of theory, institutional structure and interpretation 
of the evidence. In this article, legislative achievement of uniformity of corporate laws is argued to be a more compelling account of the pattern of corporate law reform in Canada." ${ }^{\text {"42 }}$

Cumming and MacIntosh described corporate law as a product of legislators, who supply law to corporations. The more responsive legislators of a jurisdiction are to calls for reform, the higher quality the end product will be. ${ }^{43}$ Competition exists in the market between suppliers (that is, jurisdictions) to entice firms to incorporate in their jurisdiction, so the supplier may enjoy incorporation revenues, as well as legal and corporate service work that arises with incorporation, as described above. The assumption is generally that competition exists. However, it is possible that suppliers do not respond to demands for reform, but rather converge to offer little difference in product, and therefore, choice. Cumming and MacIntosh described the latter occurrence as making it difficult for a firm to shop around. ${ }^{44}$ Without a supply-side response, there is no market for charters. Accordingly, firms enjoy none of the efficiencies in corporate laws that accompany charter competition.

When competition exists, suppliers of corporate laws can offer passive or proactive strategies. A proactive relationship between the various interest groups above fosters a keen awareness of corporate law trends and attempts to anticipate rather than react to changes.

Cumming and MacIntosh viewed Canadian jurisdictions as attempting to converge their corporate laws with federal ones, becoming indistinguishable from the CBCA and each other, rather than proactively attempting to create their own unique regimes. The uniformity hypothesis suggests that there is no supply-side competition in Canada for incorporation charters. Legislative adoption, arising from the uniformity theory, is advantageous to jurisdictions for several reasons: (1) it is the least intensive form of legislation development; (2) it reduces transactional costs because lawyers are more or less familiar with more statutes; and (3) parties can expect similar treatment from the courts of various jurisdictions, increasing certainty. These work to reduce incorporation and subsequent costs arising from initial public offerings (IPOs), takeover bids, and takeover defences. If the law is the same from jurisdiction to jurisdiction in Canada, it will be less expensive to litigate, legislate, enforce, and navigate.

Cumming and MacIntosh acknowledged that corporate laws across Canada are not uniform. They explained that "[l]egislators in different jurisdictions will predictably adopt law reforms at different rates of speed, given that corporate law reform will compete for legislative time with other matters, and that these other matters will vary in content and urgency from province to province." 45 They compare the Canadian experience to the convergence of corporate laws that the US has experienced, which the authors suggested was a result of heated competition between states. Cumming and MacIntosh distinguished uniformity and convergence: 
The American charter market — in which states like Delaware and Nevada vigorously compete for incorporation business - is far more competitive than the Canadian charter market. This competitive dynamic has produced a great deal of uniformity in United States corporate laws.... It does not seem plausible that less rigorous competition in Canada over a much shorter period of time could have produced relatively great uniformity. Hence, the emergent uniformity of Canadian corporate law is in our view most likely to attributable more to the uniformity hypothesis than the competition hypothesis. ${ }^{46}$

Cumming and MacIntosh supported this position with political, legal, and institutional arguments for the uniformity hypothesis, which can be broken into institutional and cultural barriers to interjurisdictional supply-side competition. Institutional barriers include the following: limited incentives to engage in competition, limited resources with which to compete, shared legal precedent among jurisdictions, a smaller body of corporate case law, and an inability to create a jurisdictionally responsive and skilled corporate judiciary. Cultural barriers include a lack of competitive consciousness, a loose relationship between provincial corporate bars and legislators, comparatively inexperienced practitioners, and myriad issues arising from a civil service that is disengaged with the concept of developing a charter market. All of these factors lead to what Cumming and MacIntosh referred to as lack of a credible commitment to competing for corporate charters. Certainly laws that facilitate ease of incorporation and low filing fees are preferable to drawn out and costly processes, but Cumming and MacIntosh argued that beyond superficial concerns, charter competition issues were not prescient in the minds of legislators. These arguments are discussed below.

\section{LIMITED FINANCIAL INCENTIVES}

Delaware's entire 2008 budget totaled \$3.1 billion USD, and revenue derived from the incorporation business was $\$ 566.3$ million USD. ${ }^{47}$ Because the charter business comprises such a significant share of Delaware's annual operating capital, the state cannot afford to neglect the needs and wants of corporations. ${ }^{48}$ More resources are directed at the Chancery Courts and significant efforts are put towards a proactive examination of corporate law. Corporate interests are closely monitored and legislators are to be responsive to their demands. The largesse of the Delaware state government is directly tied to its continued success in the charter market.

Cumming and MacIntosh argued that the revenue generated from provinces and the federal government indicates that it comprises less than one-tenth of 1 percent of annual

$46 \quad$ Ibid at 160 [footnote omitted].

47 State of Delaware, Office of Management and Budget "Fiscal Year Operating and Capital Budget Information” (2009), online: <http://budget.delaware.gov/fy2010/operating/10opfinsumcharts.pdf>.

48 This is perhaps best described by Macey, supra note 32 at 278 [footnotes omitted], who wrote:

Delaware relies on these revenues more than other states because for other states, revenues from corporate chartering represent only a small portion of their total budget. In other words, the high percentage of Delaware's budget that is derived from chartering revenues represents a credible (bonded) promise that the state will not renege on its earlier promise to respond in consistent ways to new phenomena. Delaware has been able to retain its dominance because it is able to offer a reliable promise that its corporation law will remain highly attractive to managers in the future. Competing states are unable to match Delaware's promise of future performance because they cannot offer the same credible bond. 
federal revenues. ${ }^{49}$ The amount is so small, they argued, that even legislation that redirects most new incorporations would result in little financial gain for larger provinces. If gains are so small, why would a province proactively seek to enter into the charter market business when there are such menial stakes? Most provinces would surely prefer to allocate that capital to maintaining roads, hospitals, and schools.

\section{LIMITED RESOURCES, EPISODIC AMENDMENTS}

The amendments to Canadian corporate law have traditionally been episodic in nature, coming in waves. Cumming, MacIntosh, and Daniels described the amending process as cumbersome and lengthy, but the Delaware process as continuous and fluid: "[Delaware corporate laws] are updated in a timely manner as needed." ${ }^{50}$ Cumming and MacIntosh questioned whether there was demand for frequent reform, particularly when the charter market does not drive any particular economy. Compared to Delaware, no Canadian jurisdiction's corporate law has a position of importance that gives the task of proactively modernizing any particular urgency. Because of the lack of urgency, there is no credible commitment to engaging in competition.

\section{Shared Legal PRECEDENT}

The structure of the Canadian judiciary creates the Supreme Court of Canada, a binding court upon all lower courts in Canada. The structure of appellant courts in the US is distinct, allowing states to house courts of last resort on certain issues - including corporate law matters. This enables a unique body of corporate law to develop in each state. While courts often take notice of corporate law developments in other states, they do so as a Canadian court would consider an Australian or American approach to legal issues.

In Delaware, corporations tend to reincorporate from other states under very specific circumstances: "[I]n anticipation of consummating three different types of transactions that might lead to litigation: going public, embarking on a merger and acquisition program and adopting antitakeover defences. The attraction to Delaware is the reduced likelihood that such litigation will succeed in the courts." ${ }^{51}$ A primary advantage to being a Delaware corporation is the sophisticated and binding body of corporate law that has been developed in that state.

\section{A SMALl BODY OF CORPORATE LAW}

Cumming and MacIntosh identified the paucity of Canadian corporate law as a unifying factor between the provinces, impeding competition. They write:

Given the small stock of corporate law precedents in Canada compared to the United States, it is only natural for Canadian judges to turn to the courts of the other provinces for guidance. So long as the stock of precedents remains relatively small, this will likely continue to be the case-although explosive growth in

Supra note 1 at 148 .

Ibid at 151.

Ibid at 155 
the jurisprudence under the corporate "oppression remedy" may well lead to the development of a more uniquely provincial jurisprudence. ${ }^{52}$

This position makes sense. Teck Corporation Ltd. v. Millar ${ }^{53}$ is an example of how widely used a case can become in Canada. Arising from a junior mining takeover bid, Teck, a 1972 British Columbia Supreme Court decision has since become an oft-cited case across Canada, arguably because there was not a higher court decision on director duties in takeover situations until Teck was enshrined as the authority on the subject.

Cumming and MacIntosh noted that securities commissions are increasingly encroaching onto the corporate law domain: "While the rules of conflict of laws establish that the applicable corporate law is that of the incorporating jurisdiction, securities legislation applies to any firm with a nontrivial number of shareholders in the province, no matter where that firm is incorporated." 54 Securities acts provide wide latitude to securities commissions to pursue issues traditionally considered corporate law issues, under their statutory public interest and discretionary powers.

\section{THE INABILITY TO CREATE A RESPONSIVE AND SKILLED CORPORATE JUDICIARY}

The judiciary is identified as a critical institutional difference between the US and Canada, which serves to prevent Canadian jurisdictions from engaging competitively in the charter market. In Delaware, the appointment process is such that Chancery Court judges are state appointees, which "ensures that the state can choose judges who will be sympathetic to corporate managers.... [B]ecause judicial appointments are a state matter, the state can decline to renew the appointment of a judge who does not decide cases in a manner suitably sympathetic to corporate concerns." ${ }^{55}$ Conversely, in Canada the federal government appoints judges, and those judges are appointees until the age of $75 .{ }^{56}$ Because of the federal appointment process, and the long duration of a judge's tenure on the bench, provinces have little ability to shape their corporate jurisprudence through the selection of judges. Realistically, provinces cannot remove judges for want of experience with corporate law matters.

Structurally, the Delaware Chancery Court operates as a separate adjudicating court with unique procedure, including a lack of jury trials. In Canada, no specialization of this kind exists. A judge could conceivably hear a murder trial, a hostile bid dispute, and the details of a juicy matrimonial trial in a relatively short span. Cumming and MacIntosh identified Ontario as an exception through the Commercial List, ${ }^{57}$ an administrative tool that enables faster resolution of specialized corporate commercial issues. Judges who are assigned to the commercial list only hear corporate and commercial cases. Cumming and MacIntosh

$52 \quad$ Ibid [footnote omitted].

(1972), 33 DLR (3d) 288 (BCSC) [Teck].

Supra note 1 at 156 .

Ibid at 157.

Supreme Court Act, RSC 1985, c S-26, s 9(2); Federal Courts Act, RSC 1985, c F-7, s 8(2).

Supra note 1 at 157 . 
dismissed the commercial list as providing similar, specialized court services: "Judges on the commercial list are largely self-selected, and have varying degrees of experience in corporate law matters. Some have no special expertise at all. Their expertise generally falls far short of that of Delaware judges." ${ }^{88}$ Delaware has showcased this ability by appointing corporate law heavyweights like Vice-Chancellor Leo Strine.

\section{THE CORPORATE BAR AND CORPORATE LEGISLATORS}

Cumming and MacIntosh argued that the relationship between the corporate bar and corporate legislators has never been close. Proposals, it was argued, begin with the bureaucracy rather than the bar, and the corporate bar is informally consulted:

$[\mathrm{H}]$ istorically, the corporate bar has typically not been the impetus for corporate law reforms, and members of the bar have not been extensively consulted on proposed reforms.... Corporate law reforms in Canada have typically been initiated and formulated by administrators, sometimes with the help of academics, or a small number of academically minded lawyers. ${ }^{59}$

This suggests that Canada’s corporate bars take a reactive approach to law reform, relying on legislative processes to engage change, and likely dictate terms. Delaware is noted for the close relationships between the state corporate bar, judiciary, and legislators.

\section{THE CIVIL SERVICE}

The Canadian civil service is also identified as a barrier to competition. Cumming and MacIntosh saw Canadian passivity in supplying corporate law, existing because of lazy, feckless, and risk-averse civil servants. ${ }^{60}$ Cumming and MacIntosh's micro-argument begins with the individual who enters the service, generally lacking the entrepreneurial bent to make it in the private sector. Once indoctrinated into the civil service, he or she will see that any incentive to be proactive is made null by the meek rewards that the state will actually receive, the realization that any success will have to be shared amongst his or her co-workers, and that any promotions to be had are likely to be based on seniority rather than an evaluation of talent or zeal. ${ }^{61}$

According to Cumming and MacIntosh, the "motives (and incentives) of bureaucrats are more important than the motives of legislators" in determining whether to enter into the charter market in any serious fashion. ${ }^{62}$ The motives of bureaucrats, simply summed, are based on expanding spheres of influence and control. ${ }^{63}$ However, Cumming and MacIntosh see this as being an implausibly weak rationale when compared to the financial incentivized arguments above. After all, they argue, “bureaucrats generally favor leisure to work,” which

$\begin{array}{ll}58 & \text { Supra note } 1 \text { at } 157 . \\ 59 & \text { Ibid at } 151 . \\ 60 & \text { Ibid at } 145 . \\ 61 & \text { Ibid. } \\ 62 & \text { Ibid at } 150 . \\ 63 & \text { Ibid. }\end{array}$


would likely "exert a powerful brake on the extent to which a bureaucrat will expand her sphere of control by attempting to attract more incorporation business." ${ }^{\prime 4}$

\section{A Critical Response to Cumming AND Macintosh}

\section{INSTITUTIONAL BARRIERS}

The arguments relating to the limited financial incentives that jurisdictions are exposed to are problematic. Firstly, the Delaware government enjoys significant charter-related revenue. Greater than direct revenues derived from in-state incorporations, bankers, corporate service firms, and lawyers generate substantial billings and demand significant ancillary services. This is similar in Canada, where it costs minimal amounts to file for incorporation, but can be costly if legal and commercial services are required for complex incorporations, amalgamations, or acquisitions. The legal and service fees that accompany the reorganizations and incorporations of firms in jurisdiction will outweigh the cost of the charter by several fold. The real reason for Delaware to continue servicing its corporate clients is likely not the revenue generated by annual fees, but by the corollary effect it has on job creation, as well as both corporate and personal state income tax.

Second, the proactivity that Cumming and MacIntosh view as of utmost importance in fostering a competitive and welcoming environment for corporate charters is somewhat disingenuous. It is equally possible that a proactive government could have damaging effects to the charter business. After all, charters do not freeze under the laws under which they are incorporated. If the laws are excessively proactive at the cost of stability, a jurisdiction may discourage chartering for want of certainty. The benefit of devoting resources to ensure corporate law pro-activity, therefore, may be misplaced.

With respect to the Ontario Commercial List, while it is true that judges self-select to become Commercial List judges, it is debatable whether the state appointment process results in judges with a greater proclivity for adjudicating corporate and commercial matters.

\section{CULTURAL BARRIERS}

Cumming and MacIntosh's arguments regarding the civil service are not well taken. There is little to distinguish the Delawarean bureaucrat from the Canadian one. Both should possess similar entrepreneurial characteristics and institutional disincentives to be proactive. Therefore, the civil service should be irrelevant to any differences in competitive intent. Governments determine priorities, and how to distribute resources. In Canada, this likely means greater emphasis on healthcare and in Delaware, corporate law. While governmental priorities may be different, the differences in efficacy of the comparative civil services is moot.

Much has changed since the publication of Cumming and MacIntosh's "The Role of Interjurisdictional Competition.” Five out of 14 jurisdictions have amended or significantly 
overhauled their acts. British Columbia and Quebec have designed statutes that do not attempt to unify with other provinces or the $C B C A$. British Columbia has chosen to continue to operate under a statute that is most influenced by the UK Companies Act $1948 .{ }^{65}$ Quebec has expressly sought to become a competing supply-side jurisdiction for incorporating companies, engaging directly with the barriers presented by Cumming and MacIntosh. Quebec's experience, detailed below, would suggest that the barriers are entirely surmountable.

\section{QUEBEC AND THE QUEBEC BUSINESS CORPORATIONS ACT}

The $Q C A$ was re-enacted and put in force as the $Q B C A$ on 14 February 2011. This is a significant development for Quebec. Until the QCA reforms in 1979 and 1980, Quebec's corporate laws were completely out of step with the rest of Canada. Daniels argued that the introduction of the CBCA in 1975 spurred significant reforms to the $Q C A$, although it retained pre- $C B C A$ characteristics that prevented continuance into other provinces. Cumming and MacIntosh dismissed this response as being merely reactionary to the federal encroachment on Quebec corporate law.

The late 1970s and early 1980s marked the first Parti Québécois majorities in Quebec, and the first national referendum. With this political backdrop, Quebec's legislative responses to the CBCA during the 1970s and 1980s have offered the most responsive evidence of competition of any Canadian jurisdiction. This evidence has been evaluated with caution by academics because of the uneasy political setting of late 20th century Quebec, but it has nonetheless had a clear relation between the amount of incorporations and the reforms of the $C B C A$ and $Q C A$.

Daniels, Cumming, and MacIntosh have commented on the politics that accompany Quebec's legislative approach to corporate law, suggesting that the province resisted adopting the $C B C A$ in its entirety because Quebec prefers to govern with a maître chez nous attitude. After the federal government introduced the $C B C A$ in 1975, the province experienced a significant drop in new incorporations. Daniels presented anecdotal evidence that officials from the province requested that the federal government raise $C B C A$ charter fees in the early 1980s to make the $Q C A$ more economically appealing. Until the implementation of the QBCA, the QCA had last been updated in 1981, reinforcing Cumming and MacIntosh's argument that corporate lawmakers in Canada lack a competitive consciousness.

Cumming and MacIntosh hypothesized that the evidence of charter competition arising in Quebec was influenced by its distinct political setting. This reflects the referendums of 1976 and 1995, and the overt desire of Parti Québécois governments to secede from the Canadian federation. In the 2000s, Quebec has more often engaged with the federal government regarding notions of culture than of self-deterministic issues. The 2006

65 BCBCA, supra note 6; Companies Act, 1948 (UK) 11 \& 12 Geo VI, c 38; Brian R Cheffins, “'User Friendly’ Corporate and Securities Law in Canada: The Role of Competitive Federalism and Mutual Recognition” in The Future of Corporation Law: Issues and Perspectives, Queen's Annual Business Law Symposium, 1997 (Toronto: Carswell, 1999) 53 at 56. 
parliamentary debate recognizing the Québecois as a nation characterized the Quebec question, rather than whether Quebec can form its own state as was the question in the 1990s. ${ }^{66}$ The Quebec sovereignty question has taken a back seat to other issues.

The introduction of the QBCA has opened a new chapter in Quebec's corporate law history. The $Q B C A$ was designed by legislators to provide the most incentive to potential incorporators to incorporate in Quebec under provincial legislation, rather than under the $C B C A$ or in another province. In designing the statute, Quebec worked closely with the local corporate bar. It solicited opinions on favourable developments in corporate legislation, and considered international developments to the business judgment rule, raincoat provisions, increased minority shareholder rights, and how to develop higher quality of corporate governance.

This express recognition that Canadian corporate law can and should be competitive, is strong evidence that a province can overcome the institutional and cultural barriers to supplyside competition as suggested by Cumming and MacIntosh. In Quebec, the province provided significant resources to the project, a relationship was fostered between the bar and the legislators, and the government embraced the competitive consciousness that is absent in Canadian corporate law as analyzed by Cumming and MacIntosh. The Quebec government is ready to compete for corporate charters.

\section{A. The DeVelopment of THE QUEBEC Business Corporations ACT}

In 1998, Marie-Andrée Latreille, a corporate lawyer at a Canadian business law firm, Davies, presented at a Barreau du Québec conference on what she understood to be an increasingly competitive environment for corporate charters and clients. ${ }^{67}$ Latreille identified changes in technology as a factor that enabled companies to reconsider incorporating in their primary place of business and to engage in jurisdiction shopping. The emergence of the Internet and sophisticated telecommunications lessened barriers to incorporation in alternative Canadian jurisdictions. Latreille saw the competition that accompanied advances in technology as both a threat and an opportunity for Quebec. She suggested that New Brunswick's success in courting Wal-Mart and Motorola to incorporate under its Business Corporations Act, ${ }^{68}$ for example, was derived from regulatory advantages of a lack of directors' liability for unpaid wages and the ability to override financial assistance regulations. She also noted Nova Scotia's success with the unlimited liability corporation, enabling American tax planners to mitigate US tax liabilities when investing in Canada. Latreille's presentation garnered some response papers by members of the Barreau on how competitive reforms could benefit Quebec lawyers and business nationally and internationally.

$66 \quad$ Reference re Secession of Quebec, [1998] 2 SCR 217.

67 Marie-Andrée, Latreille «Le phénomène du « shopping » de juridictions pour personnes morales : c'est sérieux!», [Jurisdiction Shopping for Legal Persons : Something Serious!] (Lecture delivered at the Annual Congress of the Bar of Quebec, Montreal, 1998) [unpublished]. 
By 1998 the QCA had become a niche act, generally used by small- and medium-sized enterprises with business interests solely inside Quebec, whereas the CBCA was adopted by businesses with more complex corporate structures and shareholder issues. If a company had an intention to eventually go public, it would incorporate under the CBCA. Accordingly, Quebec-based companies supplied the CBCA with more incorporations than any other jurisdiction, comprising over one third of all CBCA incorporations from 2004-2006. ${ }^{69}$

In the early 2000s, a small group of academics were calling for reform to the QCA. Stéphane Rousseau and Raymonde Crête published a public opinion in La Presse that called for reform to Quebec's corporate laws, and specifically minority shareholder protections. ${ }^{70}$ The Mouvement d'éducation et de défense des actionnaires (Médac) sent several public letters calling for reform to the Ministry of Finance in 2006. The QCA was in need of an overhaul.

Monique Jérôme-Forget, then Quebec’s Minister of Finance, Minister of Government Services, Minister for Government Administration, and President of the Treasury Board, regarded the $Q C A$ as being “considerably behind other Canadian and international company legislation as far as competitiveness is concerned."71 Jérôme-Forget commissioned a working paper to explore reform. In December of 2007, a working paper was widely circulated among law firms, academics, and non-governmental research groups.

The approach the Quebec government took in recreating the $Q C A$ into the $Q B C A$ addressed many of the bureaucratic and legislative process concerns voiced by Cumming and MacIntosh. The stated goal of the Quebec government was "that the revised Act should allow maintaining companies presently incorporated in Québec, incite existing businesses to incorporate and be attractive to foreign businesses seeking a legislative structure."72 Such goals, in effect, make this paper a market analysis for corporate law.

The Working Paper indicated a desire to use corporate legislation to enable Quebec to become a more competitive jurisdiction for corporate law shopping by larger businesses. The authors explicitly acknowledged an increased competition for charters: "Jurisdiction 'shopping' is ever more prevalent in Canada and on an international scale. In fact, directors of enterprises have access to company legislation which is increasingly competitive." ${ }^{, 73}$ The initial question was framed in the race to the top or bottom framework: the QCA maintained very little protection and very few rights and powers to shareholders generally, and practically speaking, to minority shareholders specifically. Should Quebec increase protection to shareholders or increase the protection of directors?

Finances Québec, Reform of the Companies Act Working Paper, (Quebec: Gouvernement du Québec, 2007) at 8 [Working Paper].

70

Stéphane Rousseau \& Raymonde Crête, « Un vaste chantier : Québec doit s’engager dans une approche transparente du processus de réforme de la loi sur les compagnies » La Presse Affaires (16 Septembre 2005) 7.

Working Paper, supra note 69 at i.

Ibid at 20.

Ibid at 7. 
The Working Paper identifies greater trends outside of Quebec — both within Canada and internationally — and notes that more, not fewer, rights, powers, and protections are being offered to minority shareholders, and that this has been viewed as the cornerstone of good corporate governance. The Working Paper invites the province to consider questions about potentially extending rights of dissent and oppression remedies to shareholders.

For directors, the Working Paper considers several aspects of reform, the most important of which is a bright-line adoption of the business judgment rule:

[A] possibility is establishing a legal framework in Québec based on the "management friendly" legislation in Delaware, which is the most sought after state for incorporating large American corporations. Such a choice could be warranted by the intent to place Québec in a market niche which seems to be especially popular in corporate law by immediately adopting the American approach of "Business Judgment Rule", the influence of which is irresistibly felt in Canadian corporate law and which was acknowledged by the Supreme Court of Canada in Peoples Department Store v. Wise in 2004. ${ }^{74}$

The Working Paper stresses the competing interests of QCA incorporations compared to future companies that may wish to incorporate in Quebec. ${ }^{75}$ The Working Paper considered corporate law developments in the UK. Australia, and Delaware to encourage commentary on how international modernization of corporate laws could be used within Quebec to create a more competitive and efficient set of laws.

The motive for establishing competitive business laws is stated, as Latreille noted in her 1998 presentation, as being primarily economic. The authors of the Working Paper framed the economic value of corporate law reform as a lever for economic growth. They wrote: "Considering that the Act is a lever for a competitive economic environment by attracting investments and in doing so it contributes to economic development, the reform work for this Act becomes indispensable."76 It is important to note that, while the Working Paper regards the corporate charter market in Canada as being actively competitive, the authors never

$74 \quad$ Ibid at 16. Options considered included a codification of the Business Judgment Rule as Australia has at s. 180(2) of the Australian Corporations Act 2001 (Cth) ("In general, the principle of the "Business Judgment Rule" may be invoked by directors who acted in good faith on the basis of sufficient information at the time when business decisions were made, which are now criticized and which do not involve any infringement of their duties as trustee. Courts will not intervene retroactively in such situations”); enabling a "Raincoat Provision” as Delaware has at paragraph 102(b)(7), to cover directors for shortcomings in their duties of prudence and diligence (this is specifically prohibited in all other Canadian jurisdictions); to withdraw financial tests from the act which would lessen director liability; and to restrict the removal of directors with staggered boards (the paper notes that, while this is possible with the QCA, it is a highly detailed aspect of the Delaware General Corporations Law, resulting in greater protection from takeover bids).

$75 \quad$ Ibid at 17 :

Such measures would be ... unpopular with investor protection groups, but they would ... [be] a major attraction not only for large Canadian corporations but also for American corporations....

[I]t is far from obvious that this choice will suit small enterprises, which are the main clientele under the Act. Current law grants relative remedial recourses to minority shareholders. The enactment of provisions ensuring greater protection to directors is likely to render their situation even more precarious. This could even restrict any investment by these shareholders which is essential for these small companies. 
address what the prize might be for the winner of the jurisdiction-shopping contest. Tacitly contemplated in the Working Paper is the thought that companies with more material connections to Quebec are likely to attempt to grow within the region.

\section{B. STAKEHOLDER ENGAGEMENT}

The Quebec Working Paper was widely distributed and any person or organization was invited to submit comments on what was presented. Twenty-six organizations responded, most often with significant discussion about the direction they believed Québécois corporate laws should be moving. While it appears that the corporate bar did not drive the government to reform, it was certainly at the table during the design of the $Q B C A$.

Stephen Jarislowsky, a senior member of the Quebec corporate bar and named partner of Jarislowsky Fraser Limited, stated in an open letter to the Directeur général de l'encadrement du secteur financier et des personnes morales, Maurice Lalancette, that he had suggested the Delaware example to a previous Minister of Finance. ${ }^{77}$ The Ordre des comptables en management accrédités du Québec suggested that the modernization of the laws of British Columbia be considered for its effect of making business easier, faster, and more profitable to do in that province. ${ }^{78}$ The Mouvement d'éducation et de defénse des actionnaires suggested innovative policies to increase minority shareholder protection and decrease shareholder short-termism in Quebec companies. ${ }^{79}$ Geneviève Dufour, professor of business at the University of Montréal, submitted detailed commentary on the Delaware Chancery Courts and recent Canadian case law that had engaged with Canadian corporate law principles, most notably the Supreme Court's discussion of the business judgment rule in Kerr v. Danier Leather. ${ }^{80}$

A roundtable was held at the University of Laval in 2008, bringing together various stakeholder groups to present ideas and discuss legislative options. Latreille revisited her analysis of forum shopping competition discussion ten years after she initially presented on the idea of competitive QCA reform.

Various stakeholders recommended changes to make the Quebec Act more competitive, including white-wash resolutions, classified boards, ${ }^{81}$ raincoat provisions, greater accommodation for unanimous shareholder agreements, a codification of the business judgment rule, due diligence defences for directors, formalized oppression remedies, and the ability for the corporation to give loans to shareholders. ${ }^{82}$ The resulting changes were significant.

(11 April 2008).

82 Letter from Geneviève Dufour, Lawyer and Adjunct Professor, Droit des Affaires Université de Montréal, Faculté de Droit, to Maurice Lalancette (18 April 2008). 


\section{THE QUEBEC BUSINESS CORPORATIONS ACT, DANIELS, CUMming, AND MacINTOSH}

The QBCA was a complete metamorphosis from the outmoded QCA to a set of modern business laws. The QBCA was amended 258 times, drawing on legislative concepts found in the corporate legislation of Delaware, Alberta, British Columbia, Ontario, and the US' Model Business Corporations Act. ${ }^{83}$ The new Act includes a due diligence defence and a formal acknowledgment that directors only owe a duty of care to the corporation rather than shareholders or other corporate constituencies. ${ }^{84}$

For small- and medium-sized enterprises, the Act streamlines the process of incorporation and provides simple yet flexible rules for doing so. ${ }^{85}$ Furthermore, corporations under the QBCA with one shareholder are now exempt from AGM provisions and certain organizational provisions. ${ }^{86}$ Minority shareholders are afforded a new set of rights including the right to table a shareholder's proposal at AGMs, and an expansive approach to when shareholders can have their shares redeemed. ${ }^{87}$ Quebec, in undertaking such drastic reform and not simply aligning with the $C B C A$, strays significantly from what Daniels and Cumming and MacIntosh would expect.

\section{DANIELS’ QUEBEC}

In the years after the introduction of the CBCA, Daniels viewed Quebec as being highly cross-elastic: contractions in Quebec incorporations matched the increase of federal incorporations and vice-versa. Daniels also noted that there was a correlation between incorporations and broader political movements within the province. From 1976 until 1985 the separatist Parti Québécois enjoyed a majority in the Quebec National Assembly. This brought with it perceived political instability, which Daniels identified as a motive for incorporations under the $C B C A .^{88}$ Daniels notes that federal incorporations dropped from 19,297 in 1984 to 11,652 in 1986, although he attributes the drop to a jump in CBCA filing fees rather than the election of Robert Bourassa's Liberal government in December $1985 .{ }^{89}$

\section{CUMMING AND MACINTOSH’S QUEBEC}

Cumming and MacIntosh identify Quebec as anomalous in the Canadian charter market. They regard the province as providing the best evidence of competition for corporate charters, but they disagreed with Daniels' view that the province's charter market was highly elastic with the $C B C A$. Cumming and MacIntosh raised issues about the confidence charterseekers may have being tied to Quebec: "separatist sentiment in Quebec has raised fears that the Quebec government will expropriate corporations with significant assets in Quebec (as

American Bar Association, Committee on Corporate Laws, Model Business Corporations Act.

Bill 63, Business Corporations Act, 1st Sess, 39th Leg, Quebec, 2009 (assented to 4 December 2009), SQ 2009, c 52, Explanatory Notes.

Supra note 10, ss 90-92, 100-101, 151, 240, 242, 244-45.

Ibid, ss 177-78, 217.

Ibid, ss 195-99, 221-23, 371-410.

Supra note 3 at 168.

Ibid. 
it did to the Asbestos Corporation Limited, in order to save jobs in Quebec)." ${ }^{90}$ This suggests that a charter-seeker would prefer the security of a federally based incorporation than one based in Quebec.

The unique politics of Quebec are a hurdle to competition. The maîtres chez nous attitude that Quebec has taken with its opposition to national securities regulation is prevalent in its regard for corporate laws. The Quebec example is a classic passive competition example. Cumming and MacIntosh hypothesized: "If law matters, then one would predict that the adoption of the federal changes would have led many of those who otherwise would have incorporated in Quebec to choose to incorporate federally." ${ }^{\text {"11 }}$ Only after losing market share was there action.

Cumming and MacIntosh also noted that Quebec is a civil law jurisdiction, which would operate as a barrier to entry for many corporations. Lawyers in other provinces would not be familiar with the legal system and therefore would be hesitant to recommend incorporating in a jurisdiction that does not share the jurisprudential underpinnings of other common law jurisdictions. ${ }^{92}$

\section{QUEBEC EMBRACES SUPPLY-SIDE COMPETITION}

The development of the QBCA addresses almost every non-institutional issue raised by Cumming and MacIntosh as barriers to competition in the Canadian charter market. The corporate bar is large and sophisticated, as well as engaged in the legislative affairs of the province. Quebec has made the process a priority, placing a high profile minister on the project and developing significant discussions between corporate law academics, practitioners, and interest groups. Corporate law there has been identified as a lever for economic growth by attracting new business to the province both domestically and from abroad. Quebec considered examples of international developments in corporate law to create the $Q B C A$.

If Cumming and MacIntosh were correct, one would expect Quebec to do as Ontario did and amend the Quebec Act to reflect changes to the CBCA made in the early 2000s. Alternatively, Quebec could have adopted provisions from the British Columbia Business Corporations Act. ${ }^{93}$ Creating an environment where Quebec could compete for incorporations was a legislative focus, as opposed simply to aligning Quebec with the $C B C A$. Instead of looking solely at economic incentives as drivers for competitive laws, I argue that Quebec's political interest in expanding provincial culture and language laws is the prime motivator for the development of the QBCA. Economic motives alone do not offer a compelling explanation of Quebec's approach to its corporate laws.

90 Douglas J Cumming \& Jeffrey G MacIntosh, "The Rationales Underlying Reincorporation and Implications for Canadian Corporations” (2002) 22:3 Int’l Rev L \& Econ 277 at 297.

Supra note 1 at 152 .

Supra note 90 at 297.

Supra note 6. 


\section{WHY QUEBEC?}

Cumming and MacIntosh have identified a problem with the example of Quebec: the secession question has had a manner of informing most of what happens in that province. Quiet Revolution, maîtres chez nous Quebec is 50 years old, but it is relevant to the Quebec electorate and the government that it forms. Accordingly, it is important to note that when Quebec enters into competition or conflict on various topics - particularly with the federal government - it is often reflective of a greater political movement than simply of the matter at hand. This must inform the reading of the QBCA and its formation. Rather than simply enjoying the increase in incorporation revenue, accompanying legal services, and potential economic encouragement, as other jurisdictions do, the Quebec government likely sees a competitive approach as a defence of its relative power in the face of an ever-encroaching federal government.

Macey and Kostel's public choice theory helps to explain the reasoning behind Quebec's newfound drive to provide competitive corporate laws, but only if it is broadened to include Québecois cultural stakeholders as interested agents as well. Quebec's bar, alongside notable academics such as Stéphane Rousseau and Raymonde Crête, were demanding modernization, and practitioners considered a modern statute to be a way to generate new revenues.

The drivers of corporate law policy that Macey and Kostel had identified existed in weak form in Quebec, as in most jurisdictions in Canada. Bar societies, corporate practitioners, and commercial organizations lobby for corporate law development. Macey and Kostel use public choice theory to assess how Delaware responds to legislative demands for corporate law. In Canada, the theory enables us to discern why a jurisdiction enters into supply-side competition, and second to assess which groups may have impacted corporate law reforms. In Quebec's case, the province wished to apply its provincial language and cultural laws on as many aspects of Quebec society as possible, within Constitutional and conflicts of law limits. The Québécois public supports Quebec's linguistic and cultural legislation, and by extension would support efforts to bring businesses in Québec under the ambit of those laws.

\section{A. Cultural InTERESTS}

The $C B C A$, as a federal statute, is not entirely subject to provincial law. By creating provincial corporate legislation that is more attractive to businesses than federal legislation, Quebec seeks to increase the number of businesses that incorporate under the $Q B C A$, and thus the number of businesses that fall within the ambit of the Charte de la Langue Française. ${ }^{94}$ Quebec is engaging in competition for corporate charters, but not on economic incentives alone. For Quebec, economic motives are intertwined with cultural motives. This finding suggests that economic motives alone are not enough incentive for provinces to engage in competition for corporate charters. 


\section{CHARTE DE LA LANGUE FRANÇAISE}

The Charte de la langue française was adopted by Quebec in 1977 and is central to cultural-linguistic policy in the province. The goal of the statute is to provide a framework for the francophonisation of the Québécois workplace. The statute achieves this by broadly stating that French is the language of work, communication, commerce, and business. The Office québécois de la langue française (OQLF) is responsible for carrying out this mandate.

Loi 101 places significant regulatory burdens on business to comply with the province's language laws. The OQLF, in ensuring the francophonization of firms, is to guarantee that French is in general use at all levels of the corporation, including in meetings of the board of directors, in communication with shareholders, for all internal corporate communication, and to all clients and suppliers. ${ }^{95}$ Firms that are greater than 100 employees must form a French language committee, which is to maintain acceptable levels of francophonization within a firm. ${ }^{96}$ If the OQLF is satisfied with a firm's adoption of French as the working language, it is certified as compliant. Every firm that is certified is required to give formal reports to the OQLF describing the francophonization progress. Failure to comply with Loi 101 results in fines to corporations of $\$ 1,500$ to $\$ 20,000$, which double after a first offence. ${ }^{97}$

Loi 101 applies to all businesses in Quebec, but some aspects of CBCA corporations are outside the reach of the language laws. Most notably, $C B C A$ naming provisions under section 10 do not require the use of French when businesses are formed in Quebec. Because the CBCA is a federal statute, it is outside the reach of the jurisdiction of the OQLF in this regard. Secondly, the OQLF can encounter difficulty when a business is incorporated under the $C B C A$ and is registered to do business in Quebec, but maintains an office outside the province. It becomes difficult to determine when business is being performed in Quebec that is, when francophonization applies - and when it is not. English Quebecers can circuitously avoid full Loi 101 compliance at board levels, or when communicating to various constituencies, by using the federal statute and continuing in Quebec.

\section{EFFORTS TO HARMONIZE THE APPLICATION OF QUEBEC’S LANGUAGE LAWS}

Pierre Paquette, a member of Parliament for the Bloc Québécois, introduced a private member's bill in 2009 to attempt to address the above by amending the CBCA so that corporations that operate in Quebec would be harmonized under the jurisdiction of Loi 101 and the OQLF. Bill C-307, An Act to amend the Official Languages Act (Charter of the French Language) and to make consequential amendments to other Acts, ${ }^{98}$ sought to amend the $C B C A$ to enable corporate names to fall under jurisdiction of the OLFP. The Bill failed on first reading and was not further pursued by the Bloc Québécois in the house. The issue resurfaced during the 2011 general federal election in Canada, most notably by Gilles Duceppe, leader of the Bloc Québécois during the French language debate on 13 April 2011. 
The extraordinary efforts of Quebec to create a comprehensive legislative regime that ensures a continual francophonization of Quebec suggests that cultural-linguistic policy is a priority at the provincial level. The introduction of Bill 307 indicates how intently harmonization with the Charte de la langue francaise is sought after by Quebec interests. This is unique among jurisdictions in Canada. While the political turmoil identified by Daniels, Cumming, and MacIntosh has calmed, Quebec's language policies are of primary importance to the people and government of Quebec. The continued support for Loi 101 means that the Quebec government has political motivation to capitalize on its continued enforcement.

\section{B. The Cultural Aspect of Public Interest Theory}

The QBCA was designed with the intent of attracting business into submitting to Quebec's jurisdiction. The economic arguments of ancillary revenues derived from legal and accounting services are compounded by the full application of Quebec's cultural-linguistic regime. By presenting potential incorporators with thoroughly modern laws, which offer significant differences compared to CBCA corporations, Quebec hopes to bring more companies under the full jurisdiction of Loi 101.

Public interest theory, when applied to traditional stakeholders in Delaware, suggests that the DGCL is most reflective of the interests of the Delaware bar. Macey sees the corporate bar in Delaware, rather than shareholder or director groups, as being the most influential and organized corporate law interest group in that state. ${ }^{99}$ Accordingly, the bar enjoys the benefit of increased incorporation-related billing, through favourable laws.

Cumming and MacIntosh identified Canadian corporate bars as having been passive in their efforts at lobbying their jurisdictions for favourable legislation. If this is true for the Quebec corporate bar, logically other stakeholders would be able to take advantage of lessened competition in paying rents to legislators for favourable legislation.

The application of public choice theory to the Quebec legislative process suggests either that the theory does not have the same effect in Delaware as it does provincially, perhaps because of some economies of scale issue, or that Quebec stakeholders do not share similar abilities to pay rents as their Delaware counterparts. If the widespread public support that Loi 101 receives within Quebec is taken into account under a broadened consideration that includes cultural factors such as the identity of stakeholders, and the drivers of corporate law competition, then the Quebec electorate would be the largest, most powerful interest group in the province.

The OQLF receives complaints from individuals who believe the level of francophonization intended by Quebec's legislature is not being met. Enforcement is generally initiated with Québécois reporting contraventions of Loi 101. This active participation in the cultural defence process suggests high levels of engagement with myriad approaches to cultural-linguistic policy. Accordingly, using amendments to increase the

$99 \quad$ Jonathan R Macey \& Geoffrey P Miller, “Toward an Interest-Group Theory of Delaware Corporate Law” (1987) 65:3 Tex L Rev 469 at 506-507. 
appeal to business of incorporating in Quebec under the QBCA as a way to enforce Quebec's language laws more completely is also likely to receive significant support amongst the electorate. The introduction of Bill 307 and the frequency of general federal elections in the 2000s, combined with the narrower group of election issues presented in Quebec, have likely given Québécois corporate law reform a relatively high profile compared to other provincial Acts.

The higher profile of Quebec corporate law resulted in a heightened incentive for corporate legislators to reassess the positioning of the QCA relative to the federal government and other provinces. Not only was this the result of financial incentive, which remained constant and low as observed by Cumming and MacIntosh, but of cultural-linguistic incentives based on Quebec's unique position within Canada.

Furthermore, the idea of defending Québécois culture within provincial borders — and potentially expanding its presence outside of Quebec - is likely to elicit a Robespierrian response from Quebec's civil service, rather than submissive acquiescence as hypothesized by Cumming and MacIntosh. It would become politically safe to devote more resources to the creation of competition. In short, the electorate of Quebec, an interest group that seeks to pay rents by way of votes to the provincial government, provided sufficient incentive to create a competitive consciousness, with which corporate law reforms were undertaken with the goal of using legislation to increase Quebec's share of the charter market.

This argument follows Kostel's arguments in her article "A Public Choice Perspective," where she used public choice theory. ${ }^{100}$ She noted that groups would not lobby when the costs of collective action are high. Equally, when groups can lobby inexpensively, they will do so. In the case of Quebec, the lobby is the electorate, or, more specifically, Québécois for whom the protection of the French language is important. Kostel suggests that the theory "helps explain why legislation that is avowedly aimed at protecting shareholders is in fact motivated by a drive to protect incumbent management." ${ }^{\prime 101}$ In this case, the $Q B C A$ is avowedly aimed at creating incentives for business to incorporate under the $Q B C A$. However, it is arguable that an equally important aspect is to extend Quebec's cultural and language laws. The public choice theory seems to suggest that Quebec should have reformed its laws long ago.

What does the formulation of the QBCA tell us about supply-side competition in the charter market in Canada? It offers strong evidence that either the role of the corporate law legislator or bureaucrat has changed, or that Cumming and MacIntosh were off the mark.

\section{ConClusion}

Quebec's approach to corporate law reform is strong evidence of the existence of supplyside competition in Canada. The province appears to have additional incentive to compete for charters under the $Q B C A$ because of the province's cultural and language laws, which do not fully apply to CBCA corporations. The Quebec government recognized significant 
electoral support for full implementation of Loi 101 and has proactively attempted to increase the efficacy of the language laws by creating an attractive corporate law regime for potential incorporators.

Macey, Kostel, and Romano's public choice theory is a useful tool for analyzing how interest groups affect legislative choices. In Quebec, the theory can be broadened to include those with interests in cultural-linguistic policy — primarily francophone Québécois — and can affect the corporate law reform choices of a province.

Whether the $Q B C A$ results in measurable changes to incorporation decisions within the province, in Canada, and internationally, will determine whether Quebec's legislative experiment engaged market forces. However, that Quebec opted to surmount many of the barriers identified by Cumming and MacIntosh suggests that Canadian jurisdictions are conscious of the charter market and the positive economic effects that can accompany it.

The possibility of a Delaware of the North is flawed. The role Delaware enjoys in US corporate law has no parallel. Attempting to find or create a Canadian example is misplaced. If no state can challenge Delaware for the incorporation crown, even after having stated as much as their objective as Nevada, Pennsylvania and others have, then it seems unlikely that a Canadian example will emerge after nearly 150 years of corporate law. 